\title{
PAST IASE CONFERENCES
}

\author{
ICOTS-8 \\ "DATA AND CONTEXT IN STATISTICS EDUCATION: \\ TOWARDS AN EVIDENCE-BASED SOCIETY" \\ Ljubljana, Slovenia, July 11-16, 2010

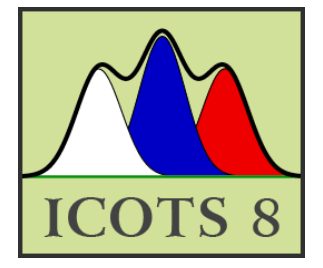 \\ The 2010 International Conference on Teaching Statistics \\ was held in the city of Ljubljana, Slovenia, July 11-16. \\ Information can be found at http://www.ictos8.org, including \\ conference proceedings, edited by Chris Reading, and videotapes \\ of plenary talks.
}

\section{CFIES 2010}

\section{2ème Colloque francophone international sur l'enseignement de la statistique} September 8 - 10, 2010

The Second International Francophone Conference on Teaching Statistics was held at Free University of Brussels, Belgium. The conference was organized under the aegis of "Société Française de Statistique," aiming to gather teachers and researchers in statistics, mathematics, education sciences, engineering of knowledge, didactics of statistics, and data processing. Many of the papers presented and an educational kit distributed at the conference can be downloaded from http://cfies2010.ulb.ac.be/ .

\section{OTHER PAST CONFERENCES}

\section{JOINT STATISTICAL MEETINGS}

"STATISTICS: A KEY TO INNOVATION IN A DATA-CENTRIC WORLD" Vancouver, British Columbia, July 31-August 5, 2010

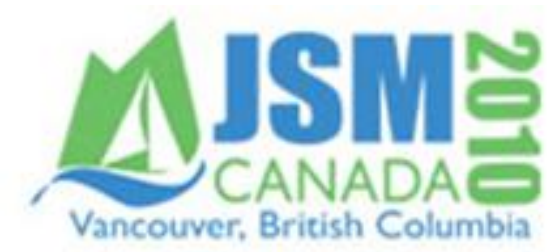

The Joint Statistical Meetings was held in Vancouver, British Columbia, July 31-August 5. The conference program and plenary session webcasts are available at the website: http://www.amstat.org/meetings/jsm/2010/ .

Statistics Education Research Journal, 9(2), 146-151, http://www.stat.auckland.ac.nz/serj (C) International Association for Statistical Education (IASE/ISI), November, 2010 


\title{
FORTHCOMING IASE CONFERENCES
}

\author{
SRTL-7 \\ THE SEVENTH INTERNATIONAL RESEARCH FORUM ON STATISTICAL \\ REASONING, THINKING, AND LITERACY \\ Freudenthal Institute, Utrecht, the Netherlands, July 17-23, 2011
}

SRTL focus on "New approaches to developing reasoning about samples and sampling in informal statistical inference," and will be hosted by Arthur Bakker, The Freudenthal Institute, Utrecht, The Netherlands at Texel Island. There will be about nine long presentations (90 minutes) and four brief ones (15 minutes). Participants work collaboratively for the whole week and presentations will lead to publications in a special issue or a book. It is not possible anymore to submit proposals, but discussants can still express their interes $t \mathrm{http} / / /$ sttl7.haifa.ac.il/ until December 1, 2010.

For more information: Arthur Bakker (a.bakker4@uu.nl)

Webstie: http://srtl.stat.auckland.ac.nz/

\section{IASE SATELLITE CONFERENCE STATISTICS EDUCATION AND OUTREACH Dublin, Ireland, August 18-19, 2011}

The seventh IASE Satellite Conference will be held immediately prior to ISI 2011 which begins August 21. The theme of the satellite is "Statistics Education and Outreach," and all submissions (by December 3) addressing the theme are welcome. Topics might include

1. The School/University interface: Activities that encourage more school students to take statistics at university; activities that lead to a more statistically literate population in general; student competitions.

2. School or University engagement with employers: How do we prepare students for the world of work and how do we involve employers in this process? What elements of our undergraduate curriculum specifically prepare our students for their future careers? How can we improve these elements?

3. Interaction with the media: How do we help journalists to have a better understanding of statistics?

4. Interaction with other professions: For example, the law, medicine, members of parliament.

5. Engagement with other academics/learned societies who use statistics: For example in geography, psychology, business studies, health care, the sciences, and social sciences.

6. School or University engagement with the local community: Improving statistical reasoning, thinking, and literacy in the general public.

For more information and abstract submission:

http://www.stat.auckland.ac.nz/ iase/conferences.php?show=iase2011 


\section{ISI 2011: 58th STATISTICS CONGRESS OF THE INTERNATIONAL STATISTICAL INSTITUTE Dublin, Ireland, August 21-26, 2011}

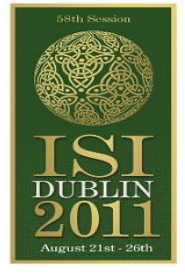

The $58^{\text {th }}$ Congress will be held in the Convention Centre Dublin (CCD). The Scientific Programme will offer delegates innovative and stimulating topics with well-balanced presentations. The Congress will include presentations on recent research, applications, and training for statisticians on key topics surrounding water, food, energy, climate change, financial systems, and urbanization. IASE is organizating ten Invited Paper Meeting sessions:

- IPS47 Applying results of statistics education research to teaching statistics Organizers: Joan Garfield (USA)

Description: How can we best apply the results of educational research to teaching statistics? How can statistics education be embedded in a research context?

- IPS48 Teaching Courses in Probability Modelling Organizer: Allan Rossman (USA)

Description: In the past there has been much greater emphasis on improving the introductory Statistics course than on how to teach Probability Modelling. This session will explore how to address this imbalance.

- IPS49 Should one attempt to integrate qualitative research approaches in traditional statistics courses? If yes, how?

Organizer: Irena Ograjensek (Slovenia)

Description: Is it appropriate for a statistics course to include qualitative research approaches? This session will consider the arguments for and against inclusion.

- IPS50 Opportunities and pitfalls of e-learning, virtual learning environments and open education resources

Organizers: Rolf Biehler (Germany), Abbas Bazargan (Iran)

Description: The purpose of this session is to consider the potentialities and pitfalls of e-learning resources and analyze their impact on statistics education.

- IPS51 Enhancing statistics education through international cooperation and the use of international data (joint with IAOS)

Organizer: Reija Helenius (Finland)

Description: Internationalising the Statistical Education experience through cooperation in training, teaching, research, and the use of international comparisons of data.

- IPS52 Teaching sampling techniques in agriculture, biology and social sciences Organizers: Carla Rossi (Italy), Álvaro González Villalobos (Argentina)

Description: How can sampling methods such as capture-recapture methods be used as a tool to introduce basic concepts in probability and statistics for biology and social sciences undergraduate courses?

- IPS53 Using popular books and entertainment in teaching statistics Organizer: Patrick Murphy (Ireland)

Description: The aim of this session is to explore how materials from popular culture may be used to enhance student engagement and understanding in the statistics classroom.

- IPS17 Risk communication to a lay audience reflecting uncertainty and variability issues (Risk Committee with IASE assistance)

Organizers: John Bailer (USA), Lutz Edler (Germany), Helen MacGillivray (Australia) 
- STS Statistical Literacy and Social Statistics Organizer: Milo Schield (USA)

Description: To review new initiatives involving the teaching of statistical literacy and critical thinking to help students read and interpret summary social statistics in the everyday media.

For more information:

Murray Cameron (murray.cameron@ csiro.au)

Patrick Murphy (IASE, patrick.murphy@ucd.ie)

Website: http://www.isi2011.ie/content/

\section{OTHER FORTHCOMING CONFERENCES}

\section{AUSTRALIAN CONFERENCE ON TEACHING STATISTICS "BUILDING CAPACITY IN STATISTICS EDUCATION" Fremantle, Western Australia, December 9-10, 2010}

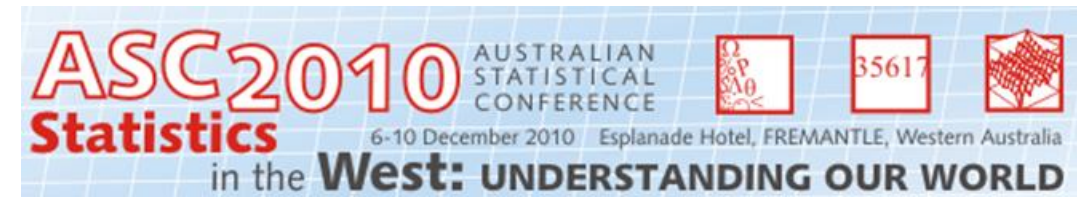

A two-day satellite conference, from 9-10 December, for statistics educators and practitioners, including universities, colleges and schools, industries, and governments will be held in conjunction with ASC2010 (Australian Statistical Conference, December 6-10, 2010). Invited and contributed papers on topics across the statistical education spectrum will be presented. Keynote speakers include Professor Delia North (University of Kwa-Zulu Natal, South Africa) and Professor Chris Wild (University of Auckland, NZ).

For more information: http://www.promaco.com.au/2010/asc/ozcots.htm

\section{USCOTS 2011 \\ UNITED STATES CONFERENCE ON TEACHING STATISTICS "THE NEXT BIG THING" \\ Embassy Suites Hotel in Cary, North Carolina, USA, May 19-21, 2011}

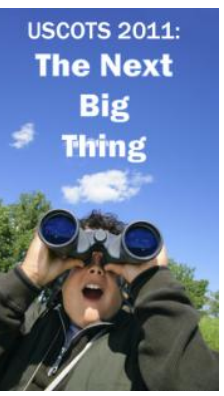

The fourth biennial U.S. Conference on Teaching Statistics (USCOTS), hosted by the Consortium for the Advancement of Undergraduate Statistics Education (CAUSE), will take place May 1921, 2011, at the Embassy Suites Hotel in Cary (Research Triangle), North Carolina. The conference theme is "The Next Big Thing." Plenary speakers include Bob delMas, Rob Gould, Dennis Pearl, Allan Rossman and Beth Chance, and Wayne Stuart.

For more information: http://www.causeweb.org/uscots/ 
PME 35

35th CONFERENCE OF THE INTERNATIONAL GROUP FOR THE PSYCHOLOGY OF MATHEMATICS EDUCATION

Middle East Technical University, Ankara, Turkey, July 10-15, 2011

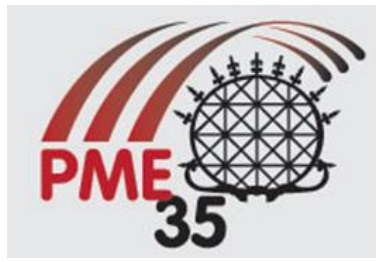

The International Group for the Psychology of Mathematics Education (PME), an autonomous body, is an official subgroup of the International Commission for Mathematical Instruction (ICMI). PME 35 provides an opportunity for mathematics educators around the world to share the most up-to-date information regarding mathematics education generally and developing mathematical thinking specifically.

For more information: http://www.arber.com.tr/pme35.org/index.php/home

\section{JOINT STATISTICAL MEETINGS "STATISTICS: AN ALL ENCOMPASSING DISCIPLINE" Miami Beach, Florida, USA, July 30-August 4, 2011}

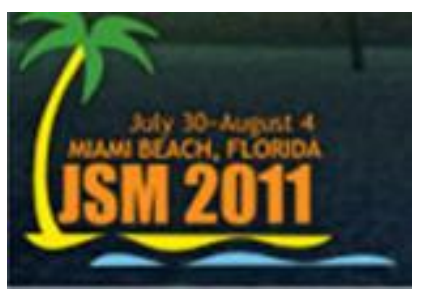

The 2011 Joint Statistical Meetings (JSM) will be held July 30-August 4, 2011, at the Miami Beach Convention Center, Miami Beach, Florida, USA. JSM is the largest gathering of statisticians held in North America. It is held jointly with the American Statistical Association, the International Biometric Society (ENAR and WNAR), the Institute of Mathematical Statistics, and the Statistical Society of Canada. Attended by over 5000 people, activities of the meeting include oral presentations, panel sessions, poster presentations, continuing education courses, exhibit hall (with state-of-the-art statistical products and opportunities), career placement service, society and section business meetings, committee meetings, social activities, and networking opportunities.

For more information: jsm@amstat.org

Website: http://www.amstat.org/meetings/jsm/2011/

\section{TH INTERNATIONAL CONFERENCE OF THE MATHEMATICS EDUCATION INTO THE 21ST CENTURY PROJECT \\ "TURNING DREAMS INTO REALITY: TRANSFORMATIONS AND PARADIGM SHIFTS IN MATHEMATICS EDUCATION" Rhodes University, Grahamstown, South Africa, September 11-17, 2011}

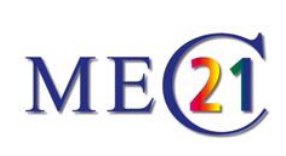

The Mathematics Education into the 21st Century Project serves as an international forum for both researchers and teachers. Innovation is our major objective and this includes special interests such as maths for living, humanizing maths education, equity and ethno-mathematics, the effective use of new educational technology in the classroom, and adopting new paradigms. We welcome proposals that deal with all aspects of innovative transformations and paradigm shifts in mathematics, statistics, science, and computer education, especially those helping to make these subjects more "alive," more "realistic," and more "accessible" to students in the future.

If you wish to present a paper or a workshop please send an email MSWord proposal of less than one page clearly indicating (in this order): 
- your name and institution

- your email address

- the title of your proposal

- a short summary or abstract of your paper or workshop (please make it clear if it will be a Paper or a Workshop)

- what area of innovative mathematics education your topic falls under

- what specific way your paper/workshop will relate to the theme of the conference. (NB please send any attachment as a normal MSWord.doc (NOT docx, pdf, rtf, nor any other formatted files)

Our conferences strongly encourage proposals of all types and we have a very open policy to accept in the programme not only refereed papers, but also workshops and contributions from teachers discussing innovative work in their schools. English will be the official language of the conference (and of the proceedings which will be printed before the conference, and available on-line afterwards).

\section{Deadlines}

- Proposals should be sent as an MSWord document by email only as soon as possible, and not later than November 25, 2010, to alan@ rogerson.pol.pl.

- For workshop presenters: Please send a "workshop summary" of 1-6 pages which will be published in the pre-conference printed proceedings and also online after the conference. This is to help you advertise your workshop to participants who will have the proceedings in their hands when they register, and also to have a permanent record of your work after the conference. Please note all detailed format requirements below apply to both workshop summaries and papers.

For further conference details, please email Alan Rogerson (alan@ rogerson.pol.pl) Chairman of the International Programme Committee

Website: http://math.unipa.it/ grim/21 project.htm

\section{ICME 12 \\ INTERNATIONAL CONGRESS ON MATHEMATICAL EDUCATION COEX, Seoul, Korea, July 8-15, 2012}

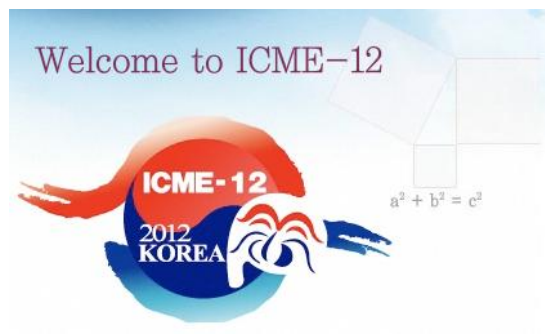

For more information: http://www.icme12.org/
The International Programme Committee for ICME-12 is putting together a rich, varied, and multi-faceted scientific programme for the Congress, with the aim of attracting and addressing the entire community of researchers and practitioners in mathematics education from all over the world. The programme will provide nourishment for thought and inspiration for everyone who takes an interest in mathematics education. 